\title{
One-Stop Physics E-Book Package Development for Senior High School Learning Media
}

\author{
https://doi.org/10.3991/ijet.v14i19 10761 \\ Alif Syaiful Adam \\ SMP Al Izzah Batu, Jawa Timur, Indonesia \\ Universitas Negeri Surabaya, Jawa Timur, Indonesia \\ Nadi Suprapto $(\bowtie)$ \\ Universitas Negeri Surabaya, Jawa Timur, Indonesia \\ nadisuprapto@unesa.ac.id
}

\begin{abstract}
Many e-Book versions of Physics learning have used to support for gaining more information. Mostly, these e-Books did not contain any virtual laboratory environment due to the student's visualization in Physics concept. For this objective, an e-Book package is developed, branded as Beboo, one-stop e-Book package completed by physics visualize animation, virtual laboratory environment, student's worksheets, supporting video and self-final test. Beboo is used to assist the second-year students of senior high school to learn static fluids concept, including the condition in static fluids and the PascalArchimedes principle applying in a daily situation. This e-Book is developed by a range of multimedia including text, pictures, diagrams, sound effect, music, video, animation in interactive, practical elements and required multiskilling that are content crating and programming. Besides, it contains the exciting part in physics learning, a laboratory activity, designed in two simulators on U-Pipe and Hydraulic Lift due to the student's understanding of the hydrostatic and pascal law systems. For a standard self-final test, Beboo provides the final test feature, shown in multiple-choice for concept achievement. In general, Beboo develops in three main stages (needs assessment, design, and development \& implementation) known as Hannafin and Peck Model and have the validation score in a range of $84 \%-94 \%$. Furthermore, Beboo should enlarge team due to more chapter coverage and Android platform support. Overall, Beboo used for an alternative use for school with no real laboratory and as the minimal point for the next e-Book development. Moreover, this learning media developed as the answer to technology integration in 21 st-century learning.
\end{abstract}

Keywords - Beboo, bilingual e-Book, Static Fluids.

\section{$1 \quad$ Introduction}

The $21^{\text {st }}$-century learning orientates to process for gaining information, solving life-relating problems, increasing adapting skill and working in different situation effectively [1]. Those particular skills are used as the preparation stage to workplace 
practice in a broad scope of the job. Nowadays, the profession selection has significant development. It is caused by massive information transfer from the internet, which needs infrastructure maintenance with specific problems. Besides, the other reason is triggered by high mobility, as the effect of transportation technology development [2]. By this condition, students must survive in another environment, step off from their daily environment. In other words, the 21 st-century learning outcome has a global vision. For further discussion, UNESCO states four pillars of education as the 21st-century learning outcomes, that are learning to know, learning to be, learning to live together and learning to do [3]. Learning to know means students should use their experiences for getting the intact knowledge, learning to be means students are trained to be an independent person and can be aware of what they will be, learning to life together means students should know that they are the part of a social life, and learning to do means students are induced to participate in daily problems solving in their life.

Those Four pillars can be succeeded by the scientific approach instruction. Based on this learning students have an opportunity to gain their knowledge based on their unique experiences, do some experiment as the characteristic of this instruction [4]. For further achievement, it acquires a relating skill such as logical thinking and scientific thinking. Sequentially, it gains through activities "observing, questioning, experimenting, associating and communicating" [5]. In Indonesia, especially for high school, it is known as Kurikulum Nasional (National Curriculum). This condition makes the scientific process in learning activities and the government is commonly relating.

In the physics learning process, meaningful information produces the entire concept [6]. Students can do the scientific process as part of the analysis of the familiar experience in their life to the physics concept [4]. One of the everyday experiences that easily found is static fluids, contain the liquids' explanation and gasses at rest. It contains many concepts as pressure, hydrostatic pressure, Pascal law, Archimedes law, capillarity, viscosity and surface tension [6].

Nowadays, technology using are quietly high. In 2017 , almost $60 \%$ of people in Indonesia have full access to the smartphone, as part of the technology. Besides, more than $55 \%$ of the household population have internet access [7]. It means many preparations to use technology in education has been acquired. Therefore, the technology supporting media should be developed well. One of them is e-Book, the electronic format of a printed book can be linked to other features for gaining particular information by increasing more experience [8]. This e-Book is not designed as the other book which focuses on the content only, but also the usability of the e-Book. Some aspects such as content, media, language and learning goal must be reached. Based on those aspects, an excellence e-Book uses meaningful, up-to-date and contextual content. It should motivate the student to gain more information by its better experience than ordinary books.

Many e-Book versions of physics learning have used as a learning source and gaining more information. It can be interpreted as the first stage of the technology using in the learning process as the $21^{\text {st }}$-century education paradigm [9]. However, e-Books that display the printed book alike in the electronic screen, did not contain a virtual 
laboratory environment due to student's visualization about relating physics concept. This virtual laboratory should represent the laboratory environment as close as possible to train the experiment skills. Besides, that visualization can be supported by sequenced animation.

In the instructional process, there is not only the experiment process but also include the assessment process. For this aspect, it can set as self-assessment for independent learning at home, inserted in e-Book. So, it can be concluded that e-Book includes the main needs as content and more features like a virtual laboratory and that worksheet, sequence concept relating animation and self-assessment features.

In addition, massive information's effect shares commonly high, include for many countries with a different language. As the global language, English plays as a tool for gaining extensive information around the world. In Indonesia, many schools respond to this condition with the international class program, by using bilingual (EnglishBahasa) in the learning process. So, the teaching material needs to develop in bilingual to succeed in this program.

\section{$2 \quad$ Method}

\subsection{Development design}

This particular study uses the Hannafin and Peck model with three main stages (needs assessment, design, and development \& implementation) [10]. Needs assessment, and development \& implementation stages applied in $11^{\text {th }}$-grade students in Sidoarjo, Indonesia. It uses a development model because of the simplicity and compatibility of the developing media. These three main stages were adapting to the figure below. 


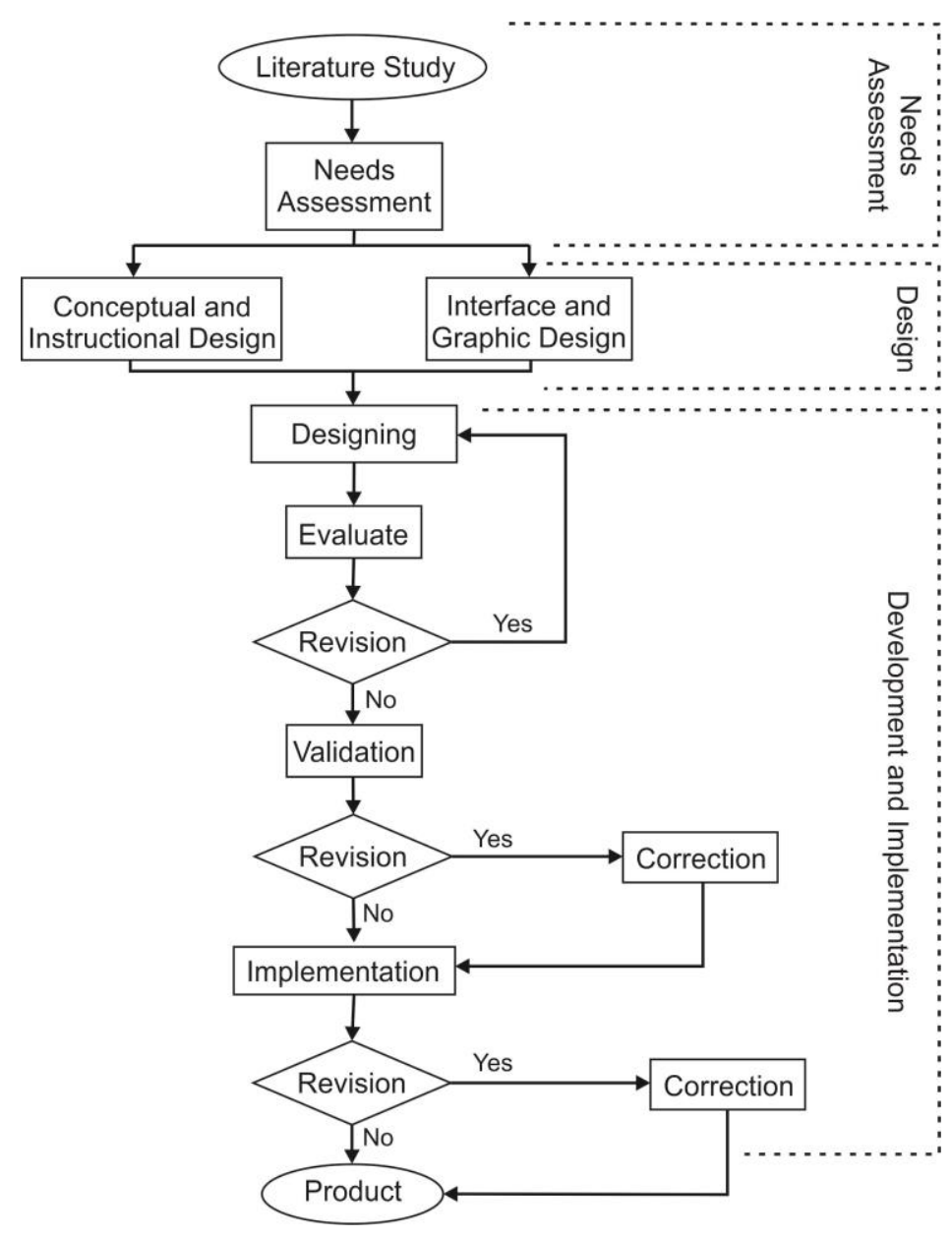

Fig. 1. Development Stages

\subsection{Data analysis}

In this particular study, data gained from the validation score of two persons as media expert who evaluate the media and two teachers in a different school in $\mathrm{Si}$ doarjo. These schools have an international program, use bilingual in the instructional process. The score measured by a questionnaire developed before based on the media and learning theories. The questionnaires consist of four aspects: content, media, language, and learning. This score interprets to score categorizing adapted from Riduwan [11] to describe the e-Book properness to use in the learning process. Besides, the supporting data come in the qualitative form as the response of the e-Book from all the experts and teachers. 


\section{Results and Discussion}

This study describes the development of physics e-Book bilingual, branded as $B e$ boo. Beboo is a one-stop media concept, e-Book's particular characteristic combination of the virtual laboratory, bilingual (English-Indonesia) content, worksheet, video, sequenced physics animation and final test as the self-assessment.

\subsection{Needs assessment stage}

Need assessment purpose is to define the students' need for physics learning media. It describes the students' expectation about e-Book and connects to national education outcome for high school, use a scientific approach. Based on the findings, most of the students $(50 \%)$ choose static fluids as the most difficult chapter in that year. Besides, the development media method has to fulfill the students' expectation and find a flash basis to develop this e-Book. It is because of the ease of the flash using and has the basic logarithm known as ActionScript to establish the virtual laboratory. This fact has clarified from the literature study before.

Another needs assessment shows the students' reason to choose static fluids as the most challenging chapter because too much memorize and difficult to understand. It means students use the inappropriate method to study physics, not doing some scientific process due to higher thinking process instead of remembering the concept. So, most of them get the deficient score for static fluids.

\subsection{Design stage}

Conceptual and instructional design: At this part, the information obtained before transformed into some conceptual and instructional design. On conceptual design, it shows students need more features instead of the ordinary e-Book, as the information source of static fluids. Then, in instructional design need to succeed in the learning process. Based on these requirements, the added features are U-Pipe and hydraulic lift simulator, student's worksheet, final test, Indonesia translation support, sample problem and review, sequential animation process (hydrostatic pressure, Upipe, hydraulic lift, buoyancy, capillarity, and viscosity) and simple experiment activity as the hands-on support.

From all features above, a simulator with worksheet support become the interesting point of this media besides the translation part. This virtual laboratory must represent the real laboratory, especially in tools setting and the effect of a particular treatment. The experiment process of this simulator is:

- Fill the U-pipe with water in a specific height so the water poured in both arms

- Put in the determined fluids to another side of the U-pipe

- After coming in equilibrium, measure the two fluids' height from the lowest border

For succeeding in the virtual experiment process, students are given a guide to ensure that they do that activity based on the scientific process. The worksheet starts 
with the density measurement benefit for many industries. Then, it shows the experiments' objectives. After reading the procedure, the student does the experiment and inserts the data to the table. For help the analysis process, Beboo has an automatically generate graph, the fluid's height in $\mathrm{x}$-axis and height of the water in the $\mathrm{y}$-axis, generate the linear gradient automatically. For the last step, the student should write a conclusion.

Interface and graphic design: The concept and instructional plan before, transformed into the chart, explain the basic interface arrangement, including the button, animation, main information display, and the media navigation. It was developed by a range of multimedia including text, pictures, diagrams, sound effect, music, video, and animation in interactive and effective elements and required multiskilling content crating and programming.

Graphic design is an essential role in user experience. Beboo is easy to use so students use this media as a learning source. Beboo displays the paper effect when a changing to the next page by pressing the keyboard arrow button, give an interactive impression about this e-Book. This effect triggered the student's attention to the media and did not change the visual experience in the printed book. Besides, it uses a simple icon and sequence animation or short video to support the students' understanding.

\subsection{Development and implementation stage}

At this part, the design of the concept and graphics build into the intact media. It uses Adobe Flash CS3 and Action Script 2.0. Although this is the old method, Flash is proven to build a media easily, produce the small size output on windows TM or iOSTM and support the needs in order to build Beboo. Besides, it is possible to make the separate parts between the contents in a page and the main part of the media, so it easier to solve the problem in a specific page.

This stage includes the designing, validating and implementing the process. In the designing process, the media is built based on the conceptual, instructional, interface and graphic design. Many features description is:

- The translation feature is accessed by clicking the English text, appeared in pop-up style and once in each paragraph

- Simulator builds as the procedure design, give three fluids as cooking oil, lubricant oil and gasoline

- Worksheet completed with automatic linear generate graph with linear regression from the data table, gradient shown as the predetermined fluid density

- Final test display in two-page, question in the left side and answer page in another side, click in answer option then press the check button for the obtained score

- Sample problem and review are inhabited by short answer questions of particular problem, mathematical or conceptual problems

- Mini laboratory states some self-observation in pressure and capillary

- Some technical supports are video, music and print support and no additional software installation in the computer device 


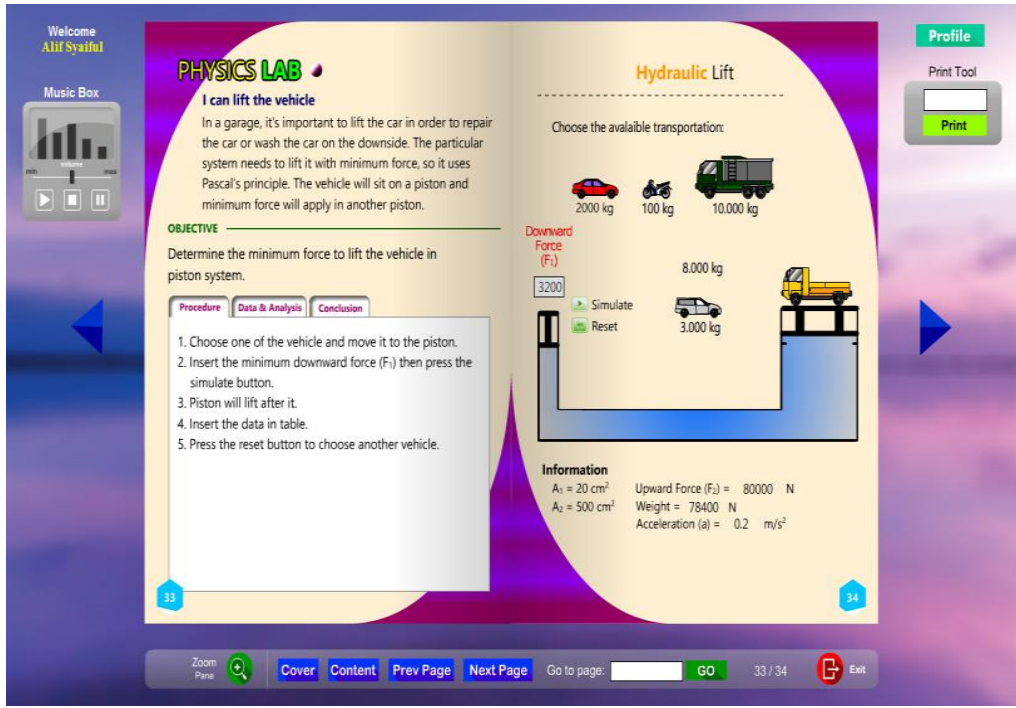

Fig. 2. Beboo display on simulator and worksheet

For make sure that Beboo feasible to use, the media should be validated by the media expert and teachers' opinion to gain more information about it. Based on the expert validation, there is no severe revision. The validation score is shown in figure 3 .

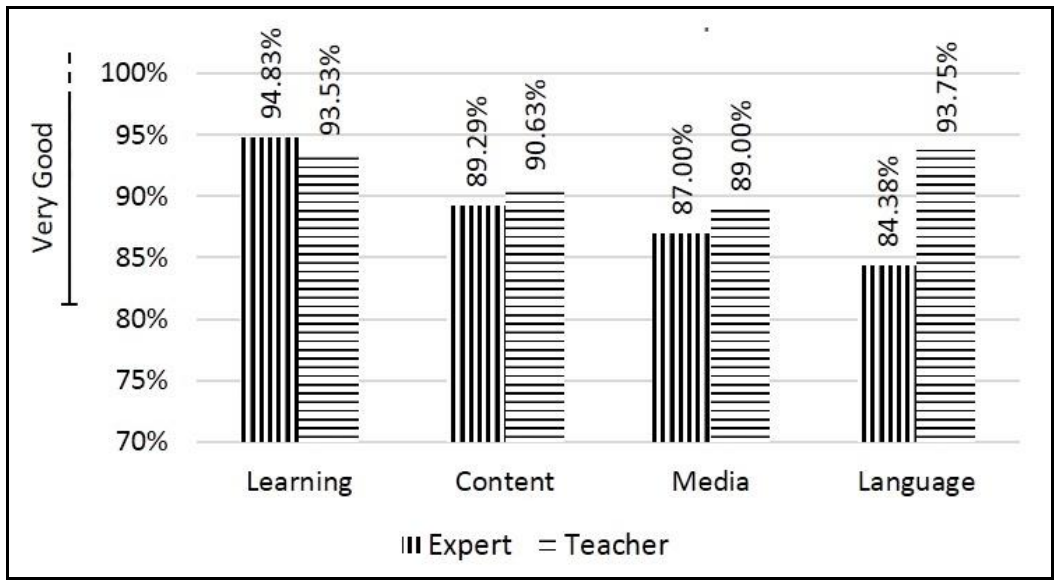

Fig. 3. Percentage of validation score in every aspect

Based on the percentage of validation score in every aspect, there are four scores in four aspects. Both experts and teacher agreed that Beboo stated in very good criteria based on Riduwan [11]. The score is in the range of $84 \%$ to $94 \%$. It means this media valid to use and suitable to support the learning activity. For further information, teachers claimed this media can be used as the alternative option for no laboratory facility in the school. 
As the implementation, the responses of students gain positive results [12]. All the aspects state in the range of percentage of $72 \%-95 \%$. It means students like to use Beboo and use the simulator correctly. They also can determine the density of fluid from that virtual laboratory. However, some physics words should be described in advance before using this media, due to the limited knowledge of the equivalent word in English.

\subsection{Discussion}

Overall, Beboo uses for an alternative use for school with no real laboratory and as the minimal point to the next e-Book development. Furthermore, the school with a physics laboratory can use effectively because of the cognitive skill's support in the laboratory. Moreover, this media developed as the answer in technology integration in the 21 st century learning with the one-stop media concept completed with virtual laboratory, bilingual (English-Indonesia) content, worksheet, video, animation, and final test.

This media uses static fluids as the content and is suitable for second-year students in senior high school in Indonesia. Reviewing the benefit of this media, Beboo should enlarge team to cover more chapters. So, it can become a complete package of the learning source for students. Besides, the smartphone users are increasing every year and this device contains the supporting feature for this media. From this fact, Beboo has an opportunity to develop in Android platform. This media is successful in providing a balance between the existence of electronic and non-electronic media, especially in physics learning [13].

\section{Conclusion}

One-stop media, an e-Book containing static fluids concept completed with two virtual laboratories (u-pipe and hydraulic lift), bilingual feature, student worksheet, sequence animation, video and final test as the self-assessment has been developed. This media soon branded as Beboo and have four aspect expert validations in a range of $72 \%-95 \%$ and stated in a very good category. It means Beboo is valid to be used, according to the static fluids concept, good language e-Book, easily accessed interface and support the learning process in scientific methods. Beboo expanded as the answer in technology integration in $21^{\text {st }}$-century learning or the alternative use for school with no real laboratory and as the minimal point to the next e-Book development. For the next media development, Beboo should enlarge team due to more chapter coverage and Android platform support.

\section{Acknowledgement}

The authors' gratitude goes to the Physics Department, Universitas Negeri Surabaya, and Indonesia as the change of the research. 


\section{References}

[1] Ravenscroft, A., S. Lindstaedt, C.D. Kloos, and D. Hernández-Leo. (2012). 21st Century Learning for 21st Century Skills. 7th European Conference on Technology Enhanced Learning, Saarbrucken, Germany. https://doi.org/10.1007/978-3-642-33263-0

[2] Rusman. (2012). Belajar dan Pembelajaran Berbasis Computer: Mengembangkan Profesionalisme Guru Abad 21. Bandung: Alfabeta.

[3] Delors, J. (1996). Learning: the treasure within; report to UNESCO of the International Commission on Education for the Twenty-first Century. Paris: The United Nations Educational, Scientific and Cultural Organization. https://doi.org/10.7788/ijbe.1996.24.1.253

[4] Sukarno. Permanasari, A. and Hamidah, I. (2013). The Profile of Science Process Skill (SPS) Student at Secondary High School (Case Study in Jambi). International Journal of Scientific Engineering and Research, 1: 79-83

[5] Arlianty, W. N. Febriana, B. W. and Diniaty, A. (2017). An analysis of learning process based on scientific approach in physical chemistry experiment. AIP Publishing, 1823: 020084-1 - 020084-7. https://doi.org/10.1063/1.4978157

[6] Serway and Jewett. (2006). Physics for Scientists and Engineers (sixth edition). California: Thomson Brook/Cole

[7] BPS. (2017). Telecommunication Statistics in Indonesia. Jakarta: BPS-Statistics Indonesia

[8] Siegenthaler, E. Bochud, Y. and Pascal, W. (2010). Improving the Usability of E-Book Readers. Journal of Usability Studies. 6 (1): 25-38

[9] Wahyuni, S. Sanjaya, I. G. M. Erman and Jatmiko, B. (2019). Edmodo-Based Blended Learning Model as an Alternative of Science Learning to Motivate and Improve Junior High School Students' Scientific Critical Thinking Skills. International Journal: Emerging Technologies in Learning, 14, 98-110. https://doi.org/10.3991/ijet.v14i07.9980

[10] Peck, I. and Hannafin, M. J. (1993). Empirically-based guidelines for the design of interactive multimedia. Educational Technology Research and Development, 41, 63-85. https://doi.org/10.1007/BF02297358

[11] Riduwan. (2010). Skala Pengukuran Variabel-Variabel Penelitian. Bandung: Alfa Beta

[12] Adam, A. S. Suprapto, N. Kholiq, A. and Mubarok. H. (2019). Students' responds in using Beboo to learn Static Fluid concept. Journal of Physics: Conference Series, 1171, 012039, 1-7. https://doi.org/10.1088/1742-6596/1171/1/012039

[13] Suprapto, N. Suliyanah. Prahani, B. K. Jauhariyah, M. N. R. and Admoko, S. (2018). Exploring physics concepts among novice teachers through CMAP tools. Journal of Physics: Conference Series, 997, 012011, 1-7.https://doi.org/10.1088/1742-6596/997/1/012011

\section{$7 \quad$ Authors}

Alif Syaiful Adam is a Teacher in SMP Al Izzah Batu, Indonesia. He also graduated from Physics Education Program in Physics Department, Universitas Negeri Surabaya, Indonesia. Email Id: nadisuprapto@unesa.ac.id

Nadi Suprapto is an Assistant Professor and Researcher in Physics Department, Universitas Negeri Surabaya, Indonesia.

Article submitted 2019-04-29. Resubmitted 2019-07-04. Final acceptance 2019-07-04. Final version published as submitted by the authors. 